\title{
A coleção Geyer doada ao Museu Imperial
}

Maria Inez Turazzi*

\section{Resumo}

Este artigo apresenta um histórico da formação e composição da coleção Geyer, a maior "brasiliana" até recentemente em mãos particulares, e relata as circunstâncias de sua doação, no ano de 1999, ao Museu Imperial, unidade do Instituto do Patrimônio Histórico e Artístico Nacional, na cidade de Petrópolis (RJ). O inventário, a conservação e a divulgação desse inestimável acervo, reunido pelo casal Paulo e Maria Cecília Geyer por mais de meio século e agora transformado em patrimônio público, têm sido realizados pelo Museu Imperial, com vistas ao pleno usufruto desses bens pelo conjunto da sociedade.

Palavras-chave: Brasiliana. Patrimônio. Museu.

\section{The Geyer collection donated to Imperial Museum}

\begin{abstract}
This article presents the history of the formation and composition of the Geyer collection, the greater brasiliana until recently in particular hands, and tells the circumstances of its donation, in the year of 1999, to the Museu Imperial, unit of the Instituto do Patrimônio Histórico e Artístico Nacional, in the city of Petrópolis (RIO DE JANEIRO). The inventory, the conservation and the spreading of this inestimable pile, gathered by the couple Paulo and Maria Cecília Geyer for more than half century and now transformed into common wealth, are being done by the Museu Imperial, intending the full use of these goods by the society as a whole.
\end{abstract}

Key-words: Brasiliana. Heritage. Museum.

"Colecionar" foi, durante longo tempo, fabricar objetos: copiar ou imprimir, reunir, classificar... E com os objetos por ele multiplicados, o colecionador torna-se um ator no encadeamento de uma história a ser feita (ou refeita), segundo novas pertinências 
intelectuais e sociais. Dessa forma, a coleção, ao produzir uma subversão dos instrumentos de trabalho, redistribui as coisas, redefine as unidades do saber, instaura um lugar de recomeço ao construir uma "gigantesca máquina" que tornará possível uma outra história. (CERTEAU, 1976, p.31)

Para as gerações que nos sucedem, registro minha inabalável confiança de que um renovado espírito público acresça mais um dever dentre as múltiplas atribuições de nossa cidadania: o de preservar as lembranças do passado artístico e cultural que são o sentido maior de toda a nação. (Paulo Fontainha Geyer) (1)

A coleção doada pelo casal Paulo e Maria Cecília Geyer ao Museu Imperial, no dia 8 de abril de 1999, juntamente com sua residência na cidade do Rio de Janeiro, representa a maior doação, realizada no século $X X$, ao patrimônio histórico e artístico nacional, ressaltando-se que essa decisão foi tomada pelos próprios colecionadores, ainda em vida, e não por descendentes ou terceiros, como costumam registrar os livros de tombo dos museus (2). A coleção Geyer reúne o maior conjunto, até então em mãos particulares, de óleos sobre tela, desenhos, aquarelas, gravuras, litogravuras, mapas, álbuns e livros de viagem sobre o Brasil, produzidos por artistas brasileiros e estrangeiros, cientistas, exploradores e viajantes de toda sorte que aqui estiveram entre os séculos XVI, XVII, XVIII e, sobretudo, o XIX. Além desse precioso acervo iconográfico e bibliográfico, a doação do casal Geyer também contempla o terreno de mais de 10.000 metros quadrados no bairro do Cosme Velho, por onde corre o rio Carioca, aos pés do Cristo Redentor, e a construção do século XVIII nele situada, com todos os seus móveis, cristais, louças, tapetes, prataria e outros objetos decorativos, tão formidáveis como toda a brasiliana ali existente.

Sabemos que, ao final do século XIX, a maior coleção bibliográfica, iconográfica e científica até então reunida por um único proprietário no Brasil foi doada por decisão de seu titular a importantes instituições culturais do país, como a Biblioteca Nacional, o Museu Nacional e o Instituto Histórico e Geográfico Brasileiro. O imperador D. Pedro II, com esse gesto, legou aos brasileiros grande parte de sua vastíssima coleção particular que havia sido deixada para trás na inesperada viagem da família imperial rumo ao exílio, depois de proclamada a República no Brasil (3). Em todos os tempos, museus, arquivos e bibliotecas do país têm se enriquecido com grandes ou pequenas doações que, mais importante do que as cifras que representam, 
exprimem o desprendimento pessoal e o espírito coletivo inspiradores do genuíno sentimento patriótico, ainda que o ceticismo dos dias atuais leve alguns a considerar esse sentimento um tanto anacrônico.

A doação do casal Geyer é admirável em todos os sentidos e, como já ressaltei em outra ocasião, não deixa de ser também, no contexto brasileiro, uma iniciativa surpreendente, sobretudo quando confrontada com o ceticismo e até mesmo a desconfiança de alguns com relação às medidas de proteção ao patrimônio histórico e artístico nacional tomadas pelo poder público (4). A iniciativa, neste caso, partiu dos próprios colecionadores, livres de qualquer pressão legal ou financeira. Estas pressões, como sabemos, foram determinantes para a incorporação de outros acervos ao patrimônio público. Preocupados com a unidade e a permanência em solo brasileiro de uma coleção "garimpada" no Brasil e no exterior por mais de cinqüenta anos - algo que Ihes parecia impossível de ser repetido -, o casal Geyer escolheu o Museu Imperial, instituição pública federal, subordinada ao Instituto do Patrimônio Histórico e Artístico Nacional, para a missão de preservar e divulgar todo esse acervo quando ambos já não pudessem fazê-lo pessoalmente.

Paulo Fontainha Geyer nasceu na cidade do Rio de Janeiro, no dia 10 de agosto de 1921, e sua trajetória como empresário, notadamente no setor petroquímico, foi marcada pela tomada de decisões rápidas e estratégicas que se orientavam por uma visão de longo prazo. Essas características, igualmente presentes em sua conduta como colecionador, foram determinantes para o sucesso de empreendimentos em setores imprescindíveis ao desenvolvimento industrial do país. A refinaria União, constituída em 1947, iniciou suas atividades em 1954; a Petroquímica União nasceria em 1965 e, quatro anos depois, formou-se a Unipar (União de Indústrias Petroquímicas S.A.); a RioPolímeros, polo de gás químico do estado do Rio de Janeiro, projetado pelo empresário desde 1986, iniciou finalmente suas atividades, em 2005.

Paulo Geyer seguiu comprando, no Brasil e no exterior, as obras que pudessem enriquecer a sua coleção, mesmo depois de doada ao Museu Imperial. Viajando, telefonando, folheando catálogos, ele procurou durante toda a sua vida, em países como Inglaterra, França, Portugal, Argentina, Estados Unidos, África do Sul e 
Austrália, as obras de arte e os objetos decorativos levados por comerciantes, cientistas, diplomatas e viajantes em geral que estiveram por aqui em épocas mais remotas. Com olhar aguçado e atenção redobrada, descobriu raridades escondidas no fundo de antiquários, negociou preciosidades com herdeiros desinteressados, vasculhou catálogos, sebos e, nos últimos tempos, endereços eletrônicos. Como colecionador desprovido de preconceito, soube adquirir também, por quantia generosa, a pintura "naify" de um artista anônimo que, displicentemente, retratava o portão de sua bela residência. Este foi o último quadro adquirido pelo empresário.

Falecido em data recente e altamente simbólica - 5 de novembro de 2004, dia da Cultura -, Paulo Geyer teve a satisfação pessoal de acompanhar de perto, desde o dia 8 de abril de 1999, o trabalho diário e sistemático de transformação de todo o acervo reunido ao seu redor, antes restrito ao conhecimento e à admiração de poucos, em patrimônio público destinado ao desfrute de toda a sociedade brasileira. Ao acolher essa doação, o Museu Imperial incorporou bem mais do que uma simples extensão, na cidade do Rio de Janeiro, de seu circuito museológico, já visitado anualmente por cerca de 300.000 crianças e adultos, brasileiros e estrangeiros. O gesto do casal Geyer, além de ampliar e diversificar consideravelmente o acervo da instituição, destacando-se neste aspecto as raridades de uma brasiliana (5) que remonta ao século XVI, incorporou também novos desafios ao funcionamento do museu e uma imensa responsabilidade no cumprimento de sua missão institucional.

\section{Por que o Museu Imperial?}

Aberto ao público em 1943, poucos anos depois da compra do Palácio Imperial de Petrópolis pela União (1939), o Museu Imperial tem recebido, desde a sua criação, em 1940, doações que vieram complementar e enriquecer o seu acervo inicial (6). Ao longo de toda a sua história, visitantes ilustres ou anônimos, colecionadores de renome, seus herdeiros ou descendentes, assim como o mais humilde cidadão e admirador do museu, confiaram à instituição a guarda de bens pessoais, familiares ou comunitários, de inegável valor simbólico para a coletividade. Em 1956, o Museu Imperial recebeu também, pela primeira vez em sua história, a doação de uma casa, com todos os bens nela existentes, localizada em área nobre da cidade de Petrópolis, posteriormente tombada pelo IPHAN. Em testamento, a viúva do médico, 
ensaísta e teatrólogo Cláudio Justiniano de Souza (1876-1954) - acadêmico que por duas vezes presidiu a Academia Brasileira de Letras - legava à União, para ser anexado ao Museu Imperial, o imóvel que passaria a receber o nome de "Casa Cláudio de Souza" (7).

Para aqueles que desconheciam esse antecedente na história da instituição, pareceu inusitada a decisão do casal Geyer de doar ao Museu Imperial, além de sua preciosa coleção, a própria casa em que residiam e continuariam a residir, por cláusula de usufruto. Outros se surpreenderam mais ainda com o montante propriamente dito da doação e, particularmente, com a iniciativa de Paulo e Maria Cecília de transformar em bem público um patrimônio particular tão raro e valioso, em seus múltiplos significados. A essas indagações, o empresário costumava responder que sua brasiliana, embora acumulada na esfera privada, orientara-se pelo mais elevado espírito público: o sentimento de brasilidade que o levara a procurar e a adquirir, sem medir esforços ou distâncias, os registros textuais e iconográficos de sua terra natal, deixados por estrangeiros, anônimos ou famosos, que aqui estiveram no passado. A doação do casal Geyer, portanto, amplamente divulgada pelos meios de comunicação da época, deu dimensão pública e merecida notoriedade a um sentimento antigo, cultivado sem alardes, por anos a fio, pelo casal de colecionadores.

A ligação de Paulo e Maria Cecília com o Museu Imperial começou, na verdade, muito antes de 1999, quando ambos concretizaram sua grande doação. Antes disso, o casal já havia emprestado algumas obras para exposições temporárias realizadas na instituição, além de doar outras peças para o acervo do Museu. No arquivo particular do empresário, um diploma conferido a Paulo Geyer, em 1979, por Lourenço Lacombe, antigo diretor do Museu Imperial, agradece-Ihe o empréstimo do retrato de D. Amélia de Beauharnais, pintado por Arnaud Julien Pallière (1784-1862), para a exposição comemorativa de seu casamento, em 1829, com o imperador D. Pedro I. O casal Geyer também doou ao Museu, em 1998, dois belíssimos leques de manufatura chinesa, da primeira metade do século XIX, comemorativos da chegada ao Brasil da família real portuguesa e da organização política do Império brasileiro (Independência, coração e sagração de Pedro I, primeira Constituição, etc). 
A escolha do Museu Imperial, portanto, não foi aleatória. A exemplo de outros visitantes e admiradores, o empresário considerava a manutenção exibida na parte interna e externa do Palácio um dos "cartões de visita" da instituição e acreditava que a integridade de sua coleção para as gerações futuras estaria assim assegurada. Essa "garantia" terá que ser, como sabemos, uma conquista diária e permanente, sobretudo porque as instituições culturais contam com recursos materiais e humanos que sempre nos parecem insuficientes. Para os técnicos da casa, a decisão do casal Geyer representou também uma espécie de reconhecimento pelos anos de trabalho, cotidiano e anônimo, de todos os funcionários que já passaram pelo Museu Imperial. Graças a esse empenho, o Museu tem sido reconhecido, há mais de sessenta anos, pela preservação, pesquisa e divulgação de um dos mais importantes acervos históricos e artísticos do país, com cerca de 250.000 documentos, 45.000 livros, 14.000 fotografias, 12.000 objetos e 2.000 pinturas e gravuras, além do próprio Palácio Imperial e mais outros 10 imóveis.

A cerimônia de assinatura do termo de doação da coleção Geyer foi realizada na própria residência do casal, desde então batizada como a "Casa Geyer" (8). A diretora do Museu Imperial, Maria de Lourdes Parreiras Horta, celebrou a data com palavras inspiradas no cenário deslumbrante que rodeava os presentes e que, no futuro, estará aberto à admiração de todos:

Se fecharmos os olhos e tudo o que está à nossa volta desaparecer, ainda podemos, fazendo um pouco de silêncio, ouvir o barulho constante e estimulante das águas que correm ali fora, a alguns metros de nós... as águas do rio Carioca, que viram nascer e batizaram a nossa cidade de São Sebastião do Rio de Janeiro. [...]

A memória e a visão do Brasil, e em especial as imagens da nossa cidade maravilhosa, recolhidas ao longo de mais de 50 anos pelo casal Geyer, fazem parte desta água viva e perene que nos garante a sobrevivência como indivíduos, como cidadãos e como cariocas. Sua permanência e sua perenidade é o que nos interessa e é o que justifica, hoje, este ato de grandeza cívica realizado por este casal de brasileiros ilustres. Mais importante do que a coisa em si, é o seu significado, o seu efeito, o seu fruto...

Decisão, portanto, longamente amadurecida, como não poderia deixar de ser, a doação de tão importante legado, para os brasileiros em geral e para os cariocas em particular, também revela o encantamento de Paulo e Maria Cecília com a cidade de 
Petrópolis, onde a família costumava passar alguns finais de semana em uma bela casa totalmente restaurada pelo casal (9). Na coleção Geyer há, por essa razão, uma preciosa iconografia petropolitana, destacando-se o conjunto ainda hoje inédito de desenhos realizados por Antonio de Paula Freitas (1845-1906), engenheiroarquiteto da Casa Imperial, onde estão representados diversos recantos pitorescos da cidade, entre 1864 e 1869. Há, também, uma bela imagem do Palácio Imperial, pintada por Nicolau Facchinetti (1824-1900), em 1869, que decora justamente a entrada da Casa Geyer. Símbolo da ligação de toda a brasiliana ali reunida com a cidade de Petrópolis e o palácio, hoje Museu Imperial, esse quadro foi escolhido pelos técnicos da instituição que procederam ao inventário do acervo doado pelo casal Geyer para receber o primeiro número de tombo (CG 00001) dos bens de sua coleção agora incorporada patrimônio público.

\section{A formação da coleção Geyer}

O colecionismo de objetos e documentos relacionados com a história, a geografia e a população do Brasil expandiu-se no século XIX, com o processo de organização do Estado nacional e a formação de uma nacionalidade "brasileira". Embora o tema merecesse considerações mais detalhadas, basta mencionar aqui o interesse de colecionadores como o próprio imperador D. Pedro II, o barão Homem de Mello, o barão Ramiz Galvão, entre outros, pela formação de brasilianas, sem falarmos, é claro, das instituições públicas e privadas do Império destinadas à guarda desse gênero de documentos (Biblioteca Nacional, Arquivo Nacional, Instituto Histórico e Geográfico Brasileiro, etc).

Adquiridas através de compra ou permuta com outros colecionadores, bem como em leilões e antiquários do Brasil e do exterior, muitas obras que hoje integram a coleção formada pelo casal Geyer pertenceram a brasilianas de grandes colecionadores do passado, como o historiador Francisco Marques do Santos (exdiretor do Museu Imperial), os empresários Cândido de Paula Machado e Alberto Soares de Sampaio (este último, pai da senhora Maria Cecília Geyer), entre outros. Em 1969, Paulo e Maria Cecília adquiriram, de uma só vez, toda a famosa brasiliana do empresário e colecionador Alberto Lee, fato que representou um grande incremento no acervo até então reunido pelo casal. 
Nas décadas de 1940, 1950 e 1960, Alberto Lee comprara no Brasil e no exterior as raridades bibliográficas e iconográficas (obras de François Froger, Jacques Funk, Adolphe d'Hastrel, J. Steinmann e muitos outros) que fariam a fama de sua brasiliana, notadamente durante as comemorações pelo quarto centenário de fundação da cidade do Rio de Janeiro, em 1965. Em correspondência com Enéas Martins Filho, datada de 23 de dezembro de 1964, o colecionador chegara a cogitar a criação de um "museu de brasiliana" como parte dos empreendimentos destinados a celebrar a data. $\mathrm{O}$ historiador, então às voltas com uma pesquisa sobre o pintor dinamarquês Paul Harro-Harring e sua passagem pelo Brasil, em 1840, respondeIhe:

Os festejos do IV Centenário começaram. Estão um tanto ou quanto fracos e desordenados, mas isso já era mais ou menos de se esperar, pois nem sempre a nossa capacidade nacional de improvisar dá certo. O Estado confiou na iniciativa privada e a iniciativa privada confiou no Estado. (10)

Para um colecionador criterioso e apaixonado pelo Rio de Janeiro como Alberto Lee, a venda de uma coleção inteira, formada por anos a fio, só pode ter sido motivada por grandes dificuldades financeiras, ainda mais porque essa venda compreendeu também o imóvel no Cosme Velho onde estava abrigada a sua brasiliana. Aos amigos, o empresário Paulo Geyer costumava dizer que comprara "uma coleção com uma casa à sua volta". O casarão no aristocrático bairro do Cosme Velho parecia ser mesmo o "lugar ideal" para reunir as pinturas, as estampas e os livros de uma brasiliana cujas obras representam, em muitos textos e imagens, exatamente aquele cenário emblemático da paisagem carioca. Lá, a família Geyer passaria a residir a partir dos anos 1970 .

Antiga sede de fazenda, situada em uma vertente do morro do Corcovado, o casarão erguido entre o final do século XVIII e o início do XIX ficou registrado na iconografia do Rio antigo, assim como em muitos relatos de viagem que hoje podem ser lidos na biblioteca da coleção Geyer. Desde as primeiras décadas do século XIX, a região já era percorrida por cariocas e visitantes da cidade ansiosos em capturar lá de cima a magnífica visão panorâmica do Rio de Janeiro. Um dos primeiros a fazê-lo foi o imperador D. Pedro I, fato registrado em texto e imagem por Jean-Baptiste Debret (DEBRET, 1834-1839, v.III). Alguns anos mais tarde, o pastor norte- 
americano Daniel Parish Kidder diria que esse era o recanto do Rio a ser visitado em primeiro lugar:

O primeiro passeio que o visitante deve fazer no Rio de Janeiro é uma excursão ao Corcovado. Pode subí-lo a cavalo até bem próximo ao cume. O início da jornada deve ser pela manhã bem cedo enquanto 0 ar está fresco e embalsamado e o orvalho ainda umedece a folhagem. A rampa não é muito forte apesar de estreita e desigual, tendo já sido sulcada pela erosão. A maior parte da montanha é recoberta por espessa mataria cuja contextura se vai modificando com a altura e na qual proliferam as mais raras e luxuriantes espécies vegetais.

$[\ldots]$

A altitude da montanha, 709 metros, é suficiente para proporcionar ao observador o maior e o mais belo panorama jamais contemplado por olhos humanos. A atmosfera estava límpida e transparente quando lá estivemos e, por mais que contemplássemos aquele panorama deslumbrante, magnífico, os nossos olhos jamais se fartavam.(KIDDER, 1940)

Em meados do século XIX, a propriedade chegou a pertencer ao barão da Glória, mas na primeira metade do século $X X$ a antiga sede de fazenda já havia dado lugar a um cortiço. Transformado em habitação coletiva, o casarão foi registrado, na década de 1950, como um dos "recantos pitorescos" da cidade (11). Alberto Lee cuidou da propriedade e nela abrigou sua coleção, embora não tenha residido no local por muito tempo. O imóvel, depois de reformado com muito bom gosto pelo casal Geyer - obra que respeitou a fachada, a volumetria e o entorno natural da construção - foi decorado pelos próprios donos com os objetos reunidos em suas inúmeras viagens (prataria portuguesa, móveis ingleses, tapetes persas, louças e cristais diversos, etc.). Uma pequena edificação anexa à residência, com cerca de 40 metros quadrados, construída por Paulo Geyer para ser a sala de cinema e jogos da família, passou a abrigar, a partir dos anos 1980, uma parte da biblioteca e do acervo iconográfico de sua brasiliana. O espírito criativo dos proprietários e a falta de espaço para uma coleção tão extensa levaram a senhora Maria Cecília a cobrir de quadros até mesmo o teto desse pavilhão. Inusitado e impactante, esse detalhe é hoje uma das curiosidades que fascinam todos os visitantes da Casa Geyer, assim como a decoração extremamente harmoniosa de seus ambientes.

As artes decorativas tiveram seu momento de esplendor no século XIX. Objetos dessa época enriquecem atualmente o acervo de vários museus, notadamente 
daqueles que se constituíram como espaços de exibição, estudo e conservação das artes decorativas. O Museu Imperial, refletindo em seu acervo essa herança cultural, possui um conjunto expressivo de louças, cristais, prataria e outros objetos representativos do apreço da aristocracia brasileira pelas artes decorativas de seu tempo. Reunidos no passado como sinônimos de sofisticação e refinamento, esses objetos são também um legado simbólico do cosmopolitismo e do apuro estético de homens e mulheres que enriqueceram seu universo doméstico com bens de consumo de grande beleza. A Casa Geyer, no futuro, será igualmente uma riquíssima fonte de pesquisa nessa área. Pois, além da brasiliana, excepcional em sua raridade e abrangência, o conjunto de móveis e objetos que decora todo o andar térreo da residência também apresenta muitas peças de grande beleza e raridade (cômodas inglesas com detalhes em marchetaria, serviços da Companhia das Índias, utensílios de prata, etc).

Dentre as artes decorativas que conheceram notável desenvolvimento no século XIX, figuram os objetos destinados à fixação e ornamentação de escadas, balaustradas, pilares e outros elementos arquitetônicos estruturais. Fabricados em cristal, cerâmica, mármore, madeira e outros materiais, esses objetos assumiram variadas designações em cada um dos países onde tal arte se desenvolveu: "boules d'escalier" (bolas de escada) na França, "bolas de sacada", em Portugal, ou simplesmente "pinhas", no Brasil. Um dos destaques da Casa Geyer é justamente o conjunto de cento e quarenta e quatro pinhas, em vidro e cristal multicolorido, adquiridas por Maria Cecília ao longo de muitos anos e hoje criteriosamente arranjadas na decoração de sua residência.

A brasiliana propriamente dita da coleção Geyer compreende uma biblioteca, com mais de dois mil títulos, sendo aproximadamente a metade formada por obras raras (livros, folhetos, periódicos, manuscritos e álbuns), e uma pinacoteca, com mais de mil obras, igualmente raras, emolduradas ou não (pinturas, desenhos, gravuras e litogravuras), bem como um pequeno conjunto de documentos cartográficos. A subdivisão da brasiliana em "livros" e "arte", uma vez que a cartografia, assim como as alfaias não haviam sido arroladas até então, corresponde a um ordenamento da coleção previamente realizado pelo empresário Paulo Geyer, com a ajuda do médico e historiador Paulo Berger. Este último foi consultor da coleção por mais de trinta 
anos, além de ser um dos maiores especialistas em iconografia e bibliografia do Rio de Janeiro (12).

O traço de Joaquim Cândido Guillobel (1787-1859), chegado ao Brasil em 1808, está entre as muitas raridades da coleção Geyer que foram estudadas por Paulo Berger e posteriormente adquiridas pelo empresário Paulo Geyer (13). Antes de ser um dos responsáveis pela construção do palácio de verão do imperador na cidade de Petrópolis, Guillobel realizou, por volta de 1814, um dos mais expressivos conjuntos iconográficos do Brasil no século XIX. Engenheiro-desenhista do Arquivo Militar do Rio de Janeiro, a originalidade do seu traço ficou consagrada pelo registro delicado de dezenas de figuras populares, "copiadas do natural" ("Irmão pedinte", "Vendedor de cestos", "Quintadeira", etc.). Essas imagens, realizadas em série e comercializadas a preços módicos, serviram de inspiração e fonte de pesquisa, nos anos seguintes, para artistas e viajantes como Debret, Chamberlain, Briggs e outros que retrataram a "alma" carioca. A coleção Geyer possui dois álbuns, um deles com encadernação de época, totalizando uma centena das "figurinhas" de Guillobel.

Um outro destaque da coleção Geyer é também a excepcional raridade de muitas obras que compõem a sua biblioteca, bem como o excelente estado de conservação desses livros. Abrangendo desde o século XVI, com obras de Jean de Lery e André Thevet; o século XVII, com destaque para o "pequeno" e o "grande" Barlaeus; o século XVIII, com sete edições sobre a invasão do Rio de Janeiro por DuguayTrouain; e o século XIX, com suas edições mais importantes, onde se incluem exemplares da Impressão Régia no Brasil, a biblioteca da coleção Geyer é também uma importante fonte de pesquisa sobre as demais brasilianas existentes no país e no exterior. Em outras palavras, a coleção também surpreende pelo que ela não contém, mas deixa entrever...

Graças à persistência, comum aos colecionadores, em referenciar as obras adquiridas e as não adquiridas, Alberto Lee e, posteriormente, Paulo Geyer recebiam de livreiros e antiquários do exterior as informações que necessitavam para sair à cata de seus "tesouros". Na biblioteca da Casa Geyer há hoje um conjunto expressivo de catálogos de leilões que remontam à década de 1920 , destacando-se entre os mais antigos, aqueles publicados pela família Maggs, da 
capital londrina. Foi John Maggs, por exemplo, amigo e correspondente de Paulo Geyer por anos a fio, quem o ajudou a contratar em Londres, em 1971, o artista Leo Wyatt para desenhar e gravar em metal, a partir de uma fotografia tirada pelo colecionador, o belo ex-libris da coleção.

Paulo Geyer também realizou anotações minuciosas, listagens sistemáticas e álbuns de recortes organizados cronologicamente para ordenar não apenas as obras que comprava, como aquelas que the escapavam. O empresário ainda organizou um arquivo detalhado sobre a formação de sua coleção: são centenas de documentos com a correspondência e/ou as notas de compra e de serviços prestados por leiloeiros, antiquários, consultores, restauradores, etc. A importância de tais documentos para o estudo da formação da coleção Geyer e sua utilidade para o histórico de cada obra são inquestionáveis, sendo raras as coleções privadas que possuem esse tipo de documentação.

A brasiliana da coleção Geyer, além de reunir um expressivo conjunto de desenhos, pinturas, manuscritos e outras obras únicas por sua própria natureza, possui também diversas gravuras, litogravuras, mapas, livros e fotografias que são, em alguns casos, os únicos exemplares conhecidos, considerando-se tanto o acervo de outras coleções particulares, como o de instituições públicas, do Brasil ou do exterior. A biblioteca possui ainda quase todas as obras publicadas por estudiosos do tema, como Vieira Fazenda, Borba de Moraes, Gilberto Ferrez, Paulo Berger e outros. Em belas encadernações, como em simples brochuras e folhetos, as raridades da coleção estarão no futuro disponíveis à consulta e ao estudo de especialistas do Brasil e do exterior, através do site do Museu Imperial.

Já a iconografia reunida na coleção Geyer concentra-se (cerca de 70\%) nas imagens que representam a paisagem e a vida social do Rio de Janeiro e seus arredores, ao longo do século XIX. A atração exercida pela geografia do lugar sobre viajantes de todos os tempos encontrou eco na preferência do colecionador "pelos contornos do Rio". O interesse de Paulo Geyer pela "iconografia que traduz um lugar, onde podemos identificar o que estamos vendo", como ele costumava afirmar, é uma das razões que explicam o processo de seleção da maior parte das 
paisagens reunidas pela coleção. Mas há outras razões, de ordem mais geral, para a maior abundância da iconografia carioca no conjunto de imagens que a integram.

Viajantes que passaram pelo Rio de Janeiro, cariocas nascidos na cidade e aqueles que a adotaram para viver, estrangeiros radicados no país e também os que, mesmo sem ter estado no Brasil, ainda assim retrataram o lugar, todos enfim que nos legaram um depoimento visual de suas percepções da paisagem carioca ajudaram a convertê-la, pela força das imagens, em bem simbólico de uma comunidade mais ampla, não fosse a iconografia um dos principais vetores de intercâmbio e aproximação entre os povos. Por isso mesmo, essa iconografia é também, ela própria, uma parcela significativa do patrimônio documental da humanidade, considerando-se o caráter cosmopolita dessas imagens e sua ampla difusão pelos quatro cantos do planeta. A coleção Geyer, por essa razão, tem sido cada vez mais procurada por pesquisadores estrangeiros que reconhecem nesse acervo uma fonte de pesquisa inesgotável para a história das relações culturais, econômicas e políticas de seus países com o Brasil.

\section{0 inventário e a conservação de um acervo}

A tarefa de transformar esse inestimável acervo pessoal em patrimônio público está sendo realizada pelo Museu Imperial, desde abril de 1999, em diversas frentes. Ao receber a doação da Casa e da coleção Geyer, a instituição recebeu também a incumbência, determinada por uma das cláusulas do termo assinado pelas partes envolvidas, de realizar um inventário dos bens que eram objeto da doação. Além de todas as obras existentes na residência da família no Cosme Velho, também estavam incluídas as telas que decoravam o escritório do empresário, no centro do Rio de Janeiro, e algumas obras localizadas na casa de Petrópolis.

O Projeto de Inventário e Conservação da Casa Geyer, coordenado e executado por uma equipe de técnicos do Museu Imperial, com o apoio temporário de prestadores de serviços especializados, foi estruturado com base em procedimentos previamente definidos e em instrumentos de trabalho especialmente elaborados (ficha de inventário, manual de preenchimento, listagem de descritores, etc). A equipe tomou como ponto de partida um inventário preliminar dos livros e da iconografia da coleção já utilizado pelo colecionador, adotando como etapas prioritárias do projeto 
a localização física e a identificação das obras, a revisão de erros e duplicidades desse arrolamento preliminar, a codificação e o registro textual das informações produzidas, a reprodução fotográfica digital dos bens da coleção. Como a cartografia e as alfaias não haviam sido até então relacionados pelo colecionador, esse trabalho foi integralmente realizado pela equipe do Museu Imperial juntamente com o novo inventário dos livros e da iconografia.

Catálogos de leilões, notas e recibos de compra dos bens, transcrições e traduções de obras que integram o acervo da Casa Geyer, bem como as anotações sobre a coleção, produzidas pelo colecionador ou por terceiros, constituíram e ainda constituem uma documentação fundamental para a identificação, o controle, a preservação e a divulgação desse patrimônio. Informações relativas à Casa Geyer (iconografia, bibliografia, exposições, etc) foram relacionadas em separado, constituindo um dossiê do imóvel que está sendo objeto de um estudo específico para fins de tombamento. Informações relativas ao empréstimo de obras, participação em exposições e referências bibliográficas da coleção também constituem documentação complementar sobre o acervo.

Como a doação previu o usufruto pelo casal de todos os bens doados, os trabalhos de inventário na Casa Geyer foram executados pela equipe do Museu Imperial com a presença e colaboração dos colecionadores, tendo sempre em mente a preocupação de não perturbar a privacidade da família. Entusiasmado com as atividades de inventário e conservação das obras e com a nova rotina doméstica, o colecionador Paulo Geyer acompanhava diariamente todo o trabalho realizado pela equipe do Museu, contribuindo com informações valiosas sobre a aquisição e o histórico de muitas peças de seu acervo. Concentrados no pavilhão anexo à residência, onde se encontra parte substancial da coleção Geyer, os técnicos da instituição seguem trabalhando no local, mesmo depois de concluído o inventário determinado pelo termo de doação, pois a pesquisa, a conservação e a divulgação desse inestimável patrimônio são, como sabemos, tarefas permanentes...

Entre abril de 1999 e junho de 2003, portanto, a equipe planejou e executou todas as etapas do Projeto de Inventário e Conservação da Casa Geyer, com vistas ao arrolamento, conferência dos dados e registro patrimonial da totalidade dos bens 
doados (4.255 itens) pelo casal Paulo e Maria Cecília Geyer ao Museu Imperial. O trabalho realizado procurou respeitar a organização dada pelo empresário à sua coleção e a distribuição espacial da mesma no interior da residência, sobretudo no que diz respeito à ordenação e localização dos itens que integram os volumes de gravuras, bem como à posição dos livros nas estantes. Essa conduta, a despeito de possíveis questões técnicas, foi considerada fundamental para garantir a continuidade do acesso e manuseio das obras pelo casal Geyer em sua residência. O inventário da coleção Geyer encontra-se em meio eletrônico, em duas bases de dados, a saber: o sistema Acervo (desenvolvido pelo Museu Imperial), contendo "alfaias" (466 itens) e "cartografia" (79 itens); o sistema PFG (pré-existente à doação e depois conferido, revisado e ampliado pelo Museu Imperial), reunindo "arte" (1.120 itens) e "livros" (2.590 itens).

Se, a curto prazo, o inventário da coleção Geyer teve por objetivo realizar tão somente um arrolamento a ser anexado ao processo de doação da Casa Geyer, a médio e a longo prazo, no entanto, essas bases de dados têm servido de suporte para um trabalho mais amplo e permanente de curadoria e divulgação do acervo. Neste aspecto, deve ser ressaltada a pesquisa documental e a revisão das informações sobre os autores, as técnicas e os temas encontrados na coleção. A reprodução fotográfica de uma parcela significativa das obras também já foi realizada (alfaias, cartografia e parte da iconografia avulsa), estando em curso a reprodução fotográfica do restante do acervo iconográfico, onde se incluem muitas ilustrações de obras encadernadas, com vistas à constante alimentação do banco de dados da coleção. Orientando-se por uma abordagem interdisciplinar, o Projeto de Inventário e Conservação da Casa Geyer é, em síntese, não somente um instrumento de controle dos bens doados pelo casal, como também uma fonte de pesquisa e de documentação museográfica.

As atividades de conservação da Casa Geyer realizadas pela equipe do Museu Imperial e, eventualmente, por especialistas contratados, têm procurado, por sua vez, conciliar as recomendações técnicas da área com as especificidades das condições de utilização e manuseio dos bens que integram a coleção. A conservação da Casa Geyer orienta-se, portanto, por um conjunto de procedimentos, baseados em recomendações técnicas, que contemplam 0 
monitoramento, o diagnóstico, a higienização e o acondicionamento de seu acervo, assim como a intervenção e o tratamento de determinados bens já comprometidos pelo tempo ou pelas condições de guarda. Nesse sentido, a substituição do acondicionamento das folhas avulsas de desenhos, aquarelas e gravuras foi considerada prioritária pela equipe, assim como o tratamento de algumas obras emolduradas que fazem parte da decoração da residência. A retirada de adesivos, remendos e suportes oxidados, o restauro de obras em papel que já apresentavam comprometimento da informação, a substituição e/ou tratamento de molduras e passe-partouts, entre outras tarefas, foram realizadas com o total apoio dos colecionadores. O histórico da presença das obras em exposições temporárias, bem como das intervenções e restaurações já realizadas em alguns itens da coleção também tem sido documentado pelo Projeto.

\section{A divulgação da coleção Geyer}

O historiador Gilberto Ferrez, além de colecionar um acervo fotográfico ainda maior do que aquele já deixado por seu avô, o fotógrafo Marc Ferrez, foi também o maior pesquisador da iconografia brasileira. Em mais de quarenta publicações sobre 0 tema, ele realizou um amplo inventário do patrimônio visivo sobre o Brasil, garimpando imagens em instituições e coleções, públicas ou privadas, brasileiras ou estrangeiras. Publicado sob o título de "Iconografia do Rio de Janeiro 1530-1890" (14), o principal projeto editorial de Gilberto Ferrez em toda a sua extensa e profícua carreira como pesquisador só veio a público, infelizmente, após o seu falecimento. A obra, desde logo reconhecida como a maior e mais completa referência bibliográfica sobre a vasta iconografia carioca, reúne a compilação, a identificação e a análise de cerca de 4.500 obras, produzidas por mais de 450 artistas, e nela estão relacionadas centenas de imagens da cidade do Rio de Janeiro pertencentes à coleção Geyer.

Procurada por muitos estudiosos, brasileiros e estrangeiros, a coleção tem sido uma fonte de pesquisa imprescindível para o conhecimento de vários aspectos de nossa história e de suas relações com a história de outros países. Antes de passarem ao patrimônio público, as obras da coleção Geyer só puderam estar presentes em exposições, estudos e publicações, graças à generosidade do casal Geyer com relação ao acesso e à divulgação de seu acervo particular. Fato, por sinal, que já exprimia a compreensão, para usarmos as palavras de Michel de Certeau, de ser o 
colecionador "um ator no encadeamento de uma história a ser feita" (CERTEAU, 1976, p.31).

Em 1972, por ocasião do sesquicentenário da Independência do Brasil, a Galeria IBEU, no Rio de Janeiro, abrigou a primeira exposição exclusivamente dedicada à coleção. Intitulada "Rio de Janeiro - Visões do passado - Coleção de Paulo Geyer", a mostra reuniu 67 obras, destacando-se nesse conjunto alguns artistas com grande presença na coleção, como Georg Heinrich Lowenstern, Emeric Essex Vidal, Frederico Guilherme Briggs, entre outros. A curadoria da exposição esteve a cargo da especialista Lygia da Fonseca Fernandes da Cunha, por muitos anos responsável pelo Setor de Iconografia da Biblioteca Nacional e pesquisadora iconográfica que, como Paulo Berger, Gilberto Ferrez e outros, realizou vários estudos na coleção Geyer. No pequeno catálogo da exposição, ela afirmava:

No conjunto de excepcional qualidade, pertencente ao colecionador Paulo Geyer, escolhemos testemunhos que abrangem um período de aproximadamente cinqüenta anos. Artistas e amadores se alternam em visões espontâneas, vibrantes e coloridas, permitindonos reconstituir através de tantas preciosidades, um dos mais ricos e fecundos períodos de evolução da cidade. [...] Conhecida de poucos estudiosos, as raridades iconográficas apresentadas nas vitrines do IBEU vêm atender ao interesse e curiosidade de um grande público. (CUNHA, 1972)

Nesse mesmo ano, Paulo Geyer editou o primeiro de uma série de livros sobre sua coleção que levariam a um público ainda mais amplo, documentos textuais e iconográficos até então inéditos. Com introdução de Lygia Cunha, o livro "O barão von Löwenstern no Brasil 1827-1829" (Rio de Janeiro, 1972) reúne 47 desenhos e aquarelas do diplomata russo, naturalizado dinamarquês, que foi enviado ao Brasil para assinar um tratado de comércio e navegação. Nos anos seguintes, Paulo Geyer dedicou-se, ele próprio, à tradução dos diários do almirante inglês que trouxera ao Brasil a comitiva encarregada de reconhecer a nossa Independência. $\mathrm{Na}$ apresentação da obra "Os diários do almirante Graham Eden Hamond - 1825 1834 / 1838" (Rio de Janeiro, 1984), o colecionador afirmaria:

Meu amigo John Maggs, livreiro e antiquário de Londres, me ofereceu o diário de Sir Graham Eden Hamond.

Não creio ter tido maior prazer do que a leitura sobre sua estada no Rio de Janeiro durante julho a setembro de 1825. Escrevendo com fria objetividade sobre tudo que lhe foi dado ver 
e conhecer, Hamond nos deixou um documento dos mais interessantes sobre a vida e os costumes brasileiros.

A sua anotação, datada de 1834, à margem da página do dia 7 de setembro de 1825 , quando parte do Brasil levando os tratados da Independência, fez-me acreditar que nunca havia abandonado o hábito de escrever seu diário. Esta convicção levou-me a tentar descobrir o paradeiro dos diários correspondentes aos anos de 1834 e 1838, e, depois de encontrar em Londres uma sua descendente, Dame Evelyn Graeme, que nada me pode adiantar, recorri ao Sr. Basil Greenhill - presidente do Maritime Museum em Londres - que não só me confirmou sua existência no acervo daquele museu como, gentilmente, me permitiu microfilmá-los.

Os meses agradáveis que passei, na tradução dos diários, convenceram-me a publicá-los, acreditando que o conhecimento do seu texto será de grande interesse e curiosidade a todos os brasileiros. (GEYER, 1984)

Ainda na década de 1980, foram editadas outras duas publicações, hoje disputadas em sebos e leilões: "Aquarelas de William Smyth 1832-1834" (Rio de Janeiro, 1987) e "América austral: um viajante português no Brasil 1882-1883: cartas de Antonio Lopes Mendes" (Rio de Janeiro, 1988). Com outros dois colecionadores (Sergio Fadel e Jaime Ramasciotti), Paulo Geyer editou ainda o livro "Pinturas e pintores do Rio antigo" (Rio de Janeiro, 1990), com textos de Herculano Gomes Mathias, Paulo Berger e Donato Mello Junior. Todas essas obras podem ser consultadas no Museu Imperial, bem como na Biblioteca Nacional e em diversas bibliotecas públicas do país, para as quais o colecionador tinha por hábito enviar suas edições.

Depois da doação, o Museu Imperial passou a apoiar o casal no atendimento, sempre que possível, das solicitações de empréstimo e reprodução da coleção Geyer, bem como na divulgação desse acervo através de exposições, publicações, sites, eventos, etc. Para enfatizar a necessidade de valorização do gesto dos mecenas e dar à sociedade brasileira a noção da riqueza e importância da coleção Geyer, oferecendo ao público em geral a oportunidade de um conhecimento direto das obras que a compõem, o Museu Imperial realizou, logo no ano seguinte à doação de Paulo e Maria Cecília, uma cuidadosa exposição desse acervo. Com a curadoria de Maria de Lourdes Parreiras Horta, diretora da instituição, a mostra "Visões do Rio na Coleção Geyer" foi apresentada de 12 de setembro a 17 de dezembro de 2000, no Centro Cultural Banco do Brasil, no Rio de Janeiro, reunindo 
180 obras, entre os quais desenhos, aquarelas, óleos, gravuras e litogravuras, livros raros e álbuns ilustrados sobre o Rio de Janeiro, entre os séculos XVIII e XIX.

A exposição "Visões do Rio na Coleção Geyer" e seu respectivo catálogo (HORTA, 2000) foram resultados de uma parceria entre o Museu Imperial, o Centro Cultural Banco do Brasil e a Prefeitura da Cidade do Rio de Janeiro, com co-patrocínio da Petrobrás. O maior apoio para o sucesso do evento, contudo, foi dado pelo próprio casal Paulo e Maria Cecília. Além de desguarneceram as paredes de sua bela residência com muitas de suas obras preferidas, ambos ajudaram a agilizar a seleção das obras, a organização do catálogo e a montagem da exposição por uma equipe de profissionais, contribuindo assim para que o Museu Imperial realizasse, em curto espaço de tempo, aquela que foi considerada pela imprensa da época uma das melhores exposições do ano.

Em 2002, o colecionador Paulo Geyer, solicitou-nos a edição do livro "Tipos e cenas do Brasil imperial; a litografia Briggs na coleção Geyer", obra publicada pelo Museu Imperial e patrocinada pelo grupo Unipar (TURAZZI, 2002). O interesse pela oficina litográfica de Frederico Guilherme Briggs, um dos pioneiros dessa arte no Brasil, é dos mais antigos entre estudiosos e colecionadores da iconografia brasileira, ficando amplamente demonstrada a sua importância, já na segunda metade do século XIX, pelo catálogo da Exposição de História do Brasil, de 1881 (BIBLIOTECA NACIONAL, 1881). No decorrer do século $X X$, estampas avulsas, panoramas e álbuns da Litografia Briggs foram garimpados no exterior e "repatriados" para as coleções brasileiras. Tendo sobrevivido à ação do tempo, da natureza e dos homens, as cento e nove obras reunidas na publicação são extremamente raras, encontrando-se pouquíssimas imagens com a marca da oficina Briggs em outras coleções e instituições do país, inclusive a Biblioteca Nacional, onde foram publicadas as principais obras de referência sobre o artista. Além do catálogo já citado, a instituição também realizou, há pouco mais de trinta anos, uma edição facsimilar do álbum "The Brazilian souvenir", precedido de um estudo históricobiográfico sobre Frederico Guilherme Briggs e sua oficina (15).

O historiador Gilberto Ferrez era de opinião que as quatro vistas do "Panorama da cidade do Rio de Janeiro", desenhadas e litografadas por Briggs, "são das mais 
belas da iconografia carioca, não só pelo caráter artístico, como também pela elaboração, detalhes arquitetônicos, perspectiva e beleza dos primeiros planos". Pesquisando as estampas da oficina Briggs existentes na coleção Geyer, Ferrez observara que tais obras estavam em perfeito estado de conservação e sem cortes nas margens, isto é, com todas as legendas originais, o que nem sempre podia ser encontrado nos exemplares de outras coleções (FERREZ, 2000, p.19 e p.356).

Pelas características dessa iconografia, desprovida de qualquer luxo, por sua fragilidade intrínseca ou pelo excesso de manuseio, os exemplares de álbuns, panoramas, caricaturas e tipos de rua, publicados em série e às dezenas por Frederico Guilherme Briggs, foram desaparecendo e se tornando cada vez mais escassos. Reproduzir o conjunto reunido no livro "Tipos e cenas do Brasil imperial; a Litografia Briggs na coleção Geyer" - o mais expressivo de que se tem notícia em uma única coleção -, oferecendo-o a novas leituras e interpretações, pareceu-nos, assim, o melhor meio de promover a sua divulgação e de assegurar a sua efetiva permanência no tempo. (TURAZZI, 2002, p.22-37).

Finalmente, resta-nos mencionar aqui o tema de pesquisa que, no momento, estamos desenvolvendo com base na coleção Geyer. Trata-se de uma análise das relações entre iconografia e patrimônio, com vistas à identificação e à contextualização do papel das imagens, particularmente da cidade do Rio de Janeiro, no processo de construção da idéia de patrimônio no Brasil na segunda metade do século XIX.

Desenhos, pinturas, gravuras, litogravuras, fotografias e publicações ilustradas multiplicaram-se no decorrer dos séculos XIX e XX, por todos os cantos do planeta, constituindo-se essas imagens em uma parcela significativa do patrimônio cultural da humanidade. Por outro lado, em todas as cidades e países onde foram criadas, desde o século XIX, instituições públicas e particulares voltadas para a identificação e a preservação de seu patrimônio, a iconografia foi considerada, desde logo, um instrumento primordial dessa ação. No Brasil, como em outros países, a própria noção do que hoje chamamos patrimônio consolidou-se no imaginário coletivo como resultado, justamente, de esforços pioneiros de identificação, inventário, preservação e difusão dos monumentos históricos e artísticos nacionais, esforços 
beneficiados pela ampla utilização de registros visuais desses monumentos, tais como aqueles encontrados na iconografia brasileira.

Mas, se é verdade que o reconhecimento da paisagem como patrimônio costuma ser tributário das ameaças que recaem sobre a sua existência, a iconografia tem o mérito de, freqüentemente, assinalar a primeira forma desse reconhecimento e, não raro, orientar as primeiras ações voltadas para a sua proteção. Por essa razão, a iconografia sempre esteve associada à sua função utilitária como referência visual da paisagem (natural ou construída pelo homem) a ser preservada. No entanto, sabemos que a iconografia também tem participado da ampliação do conceito de patrimônio para além de sua configuração arquitetônica, isto é, para outros domínios da existência humana onde toda a diversidade dos bens culturais, materiais e simbólicos, de uma sociedade pode ser englobada.

Diante da complexidade crescente da definição e aplicação do conceito de patrimônio, o historiador Henry Rousso lembra-nos que esta idéia e as práticas voltadas para a sua preservação permitem "um olhar particular sobre a história", já que temos aí um indicador privilegiado da relação que uma dada sociedade mantém com seu passado, relação esta que também se transforma com o tempo (ROUSSO, 2003, p. 365-376). Nesse sentido, acreditamos que a coleção Geyer, além de ser um dos maiores patrimônios culturais da sociedade brasileira, é também uma fonte inesgotável para o estudo do papel desempenhado pelo patrimônio nas relações que mantemos com o nosso próprio passado. 


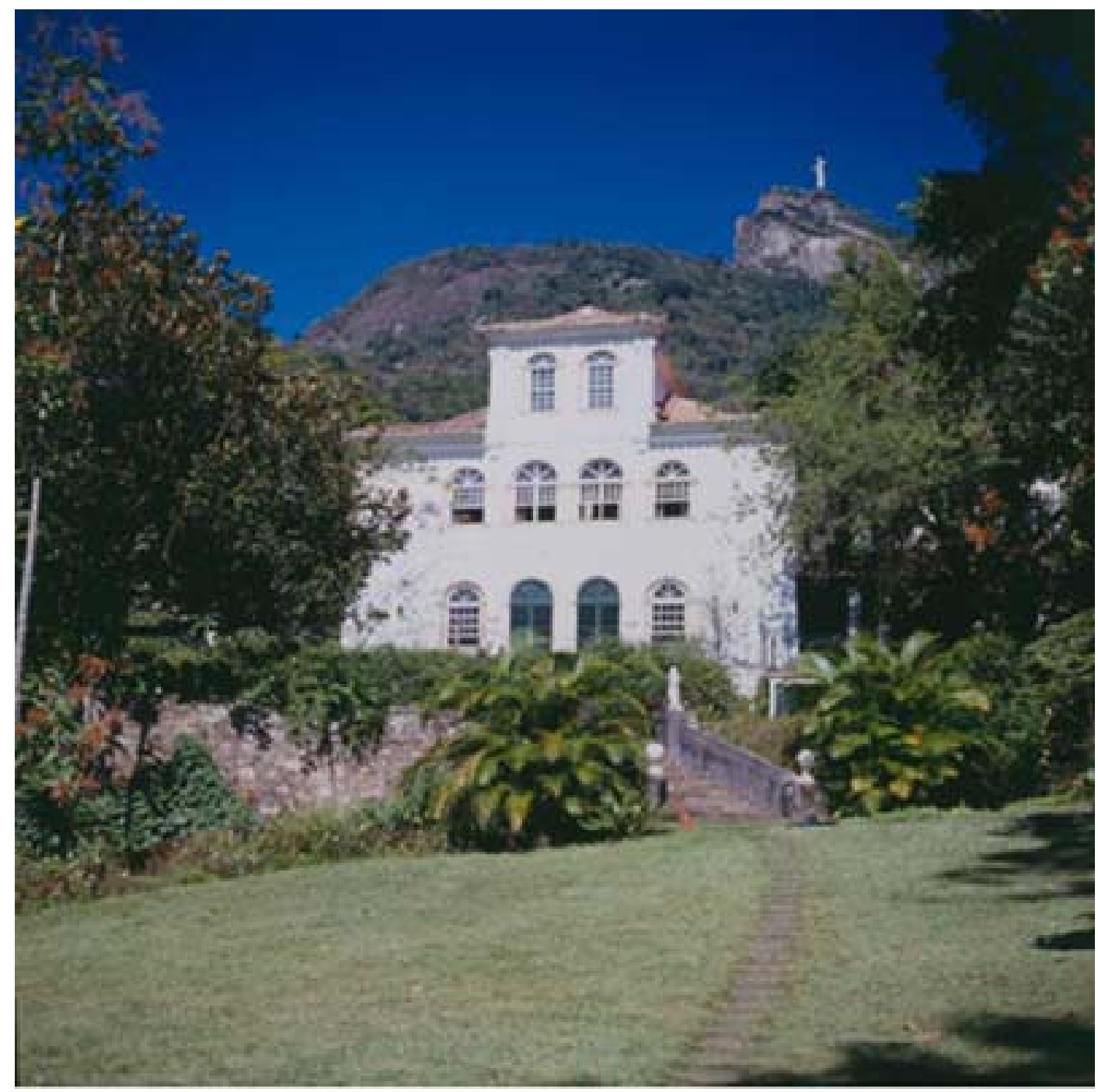

FIGURA 1 - A Casa Geyer, aos pés do Cristo Redentor, no bairro do Cosme Velho, no Rio de Janeiro. Fotografia: Pedro Oswaldo Cruz. 


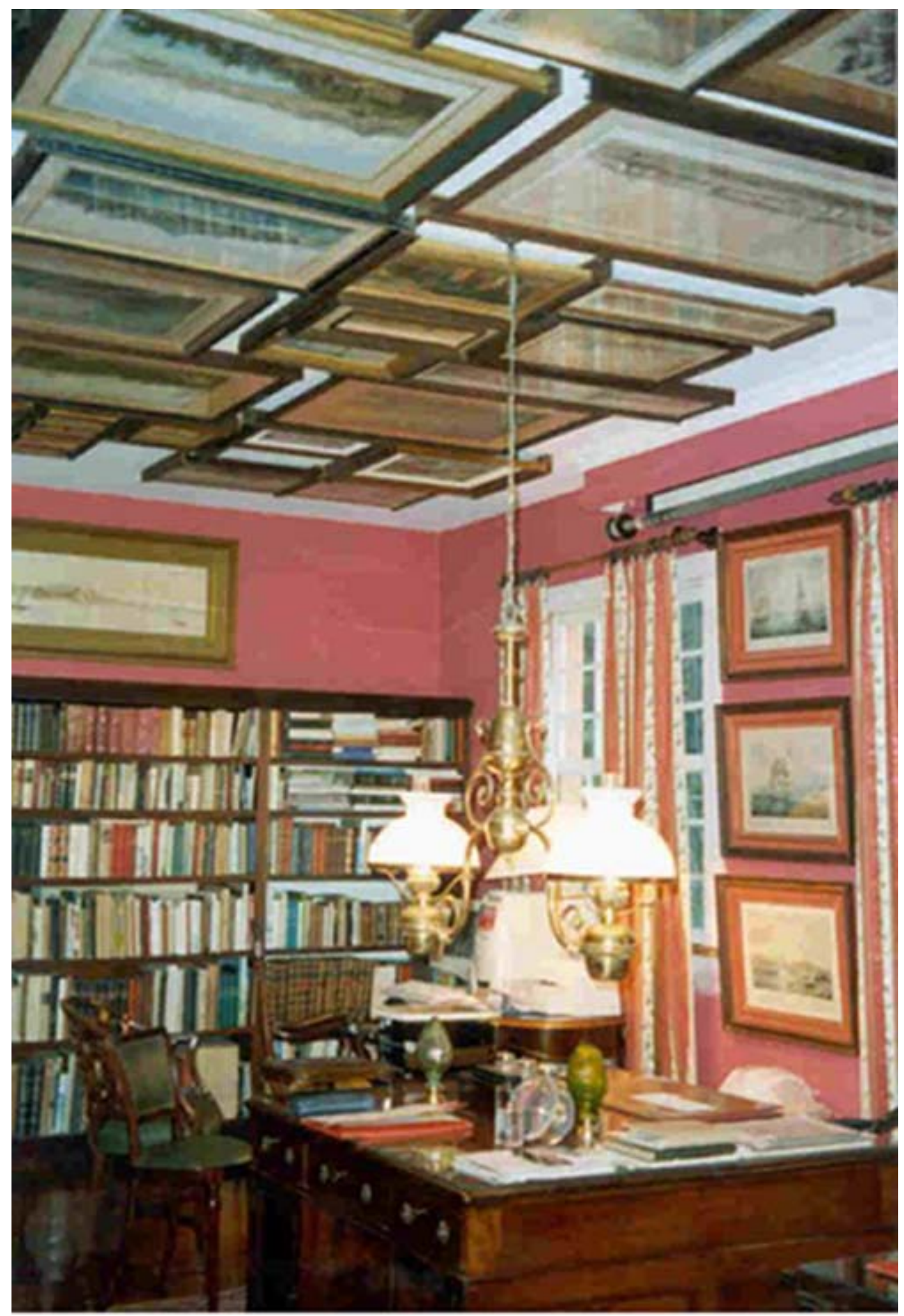

FIGURA 2 - O interior da biblioteca da Casa Geyer. 


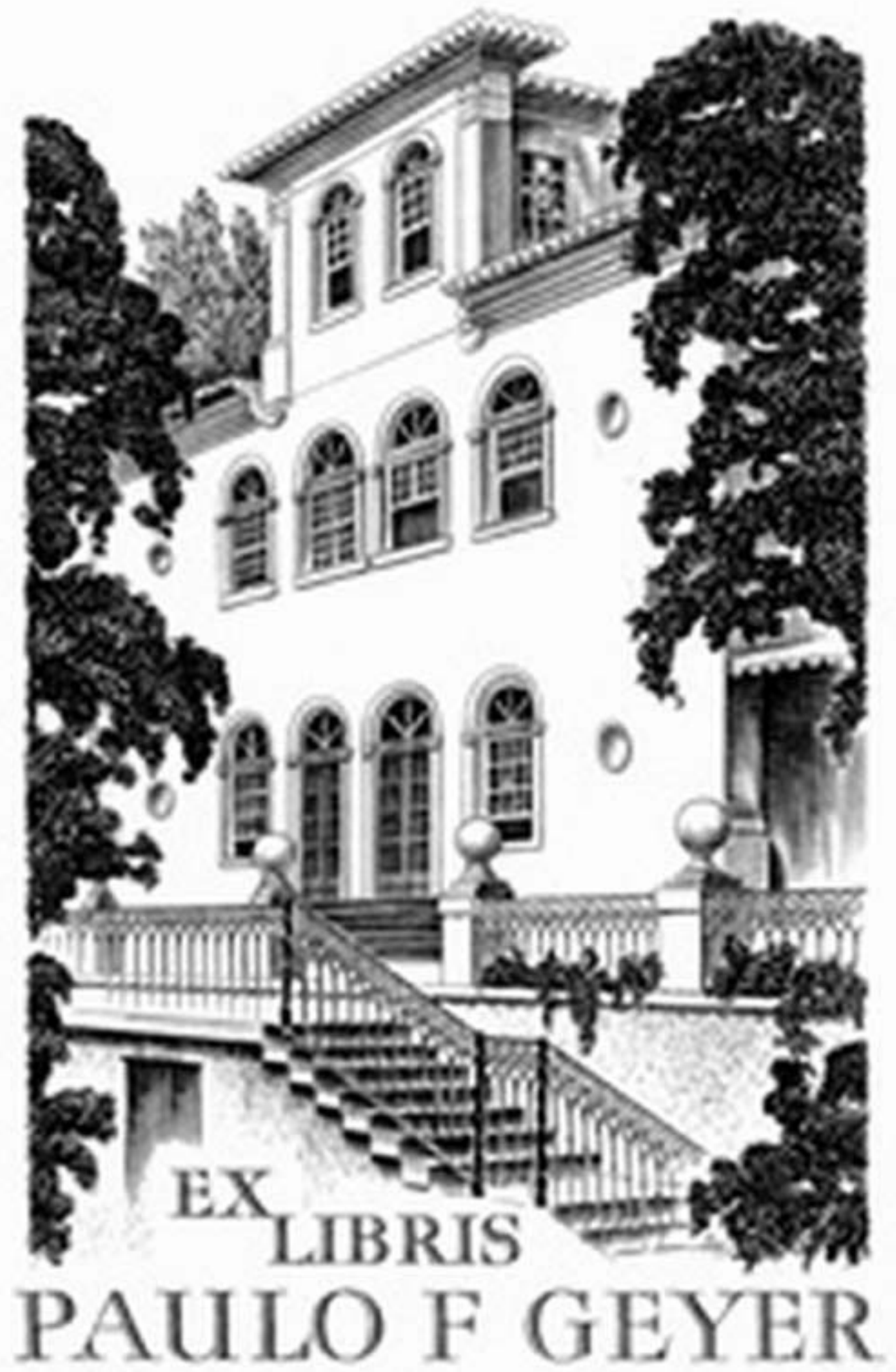

FIGURA 3 - o ex-libris da coleçăo Geyer. 


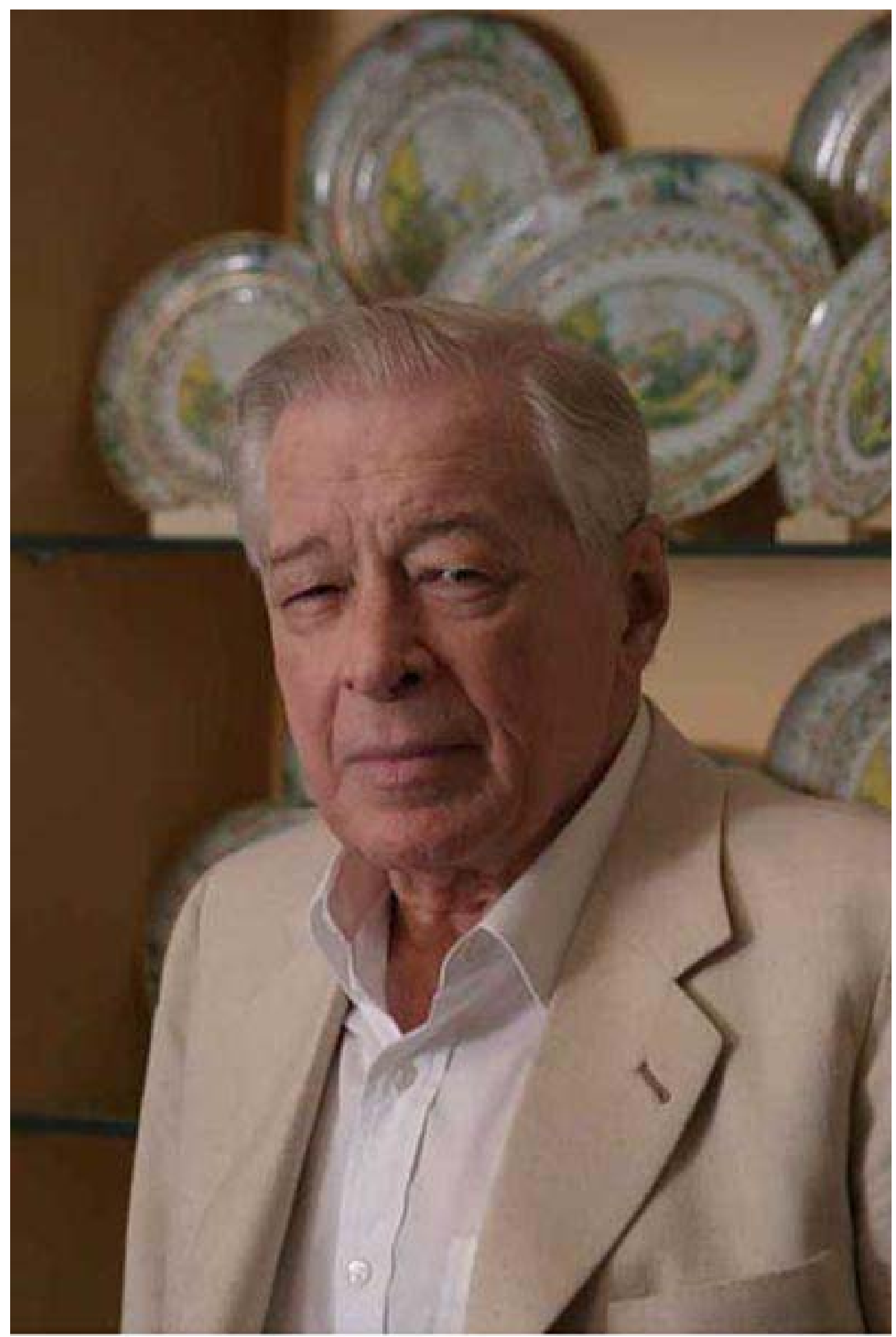

FIGURA 4 - 0 empresário e colecionador Paulo Fontainha Geyer, em sua residência, em novembro de 2003. Fotografia: Américo Vermelho. 


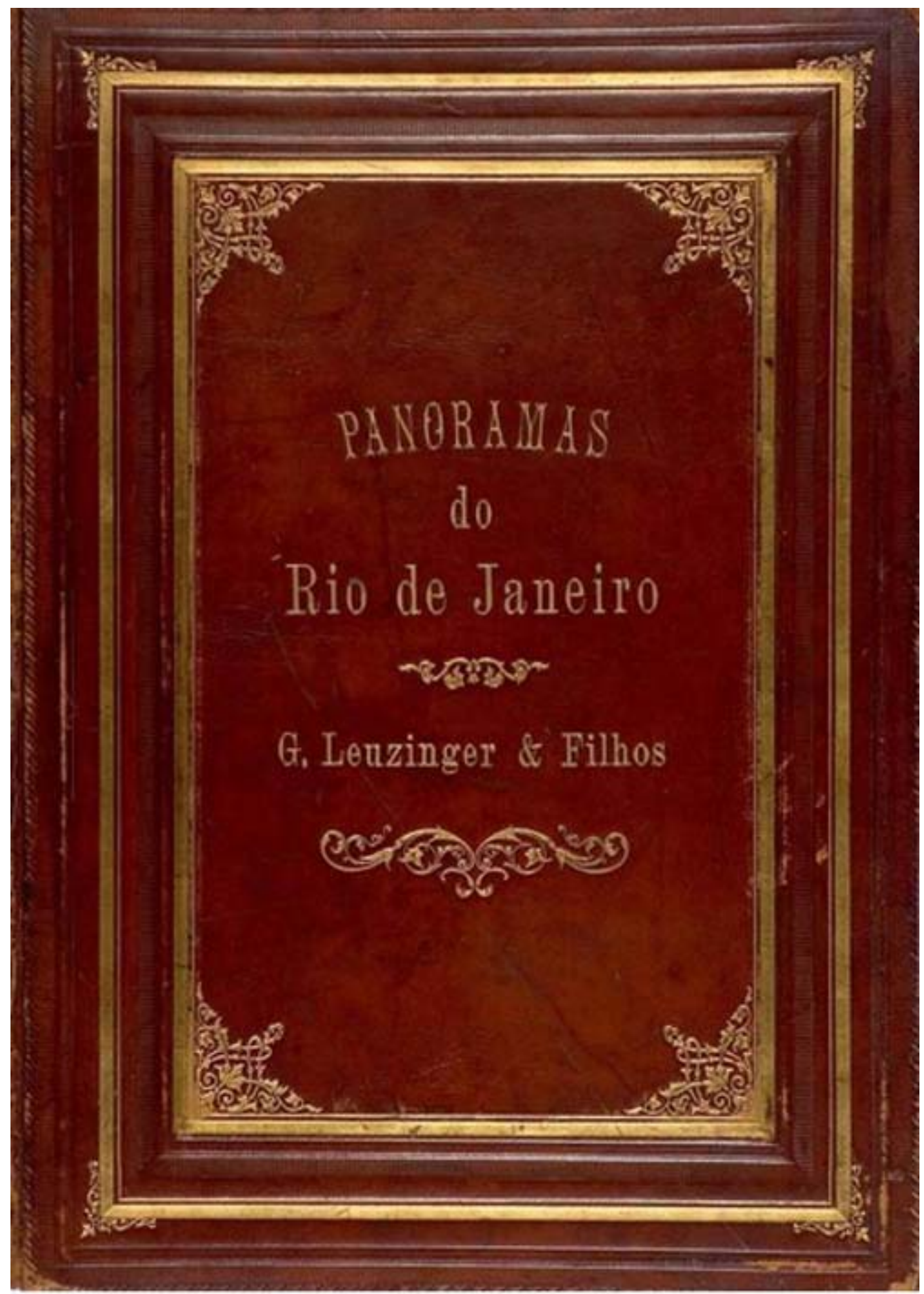

FIGURA 5 - Panoramas do Rio de Janeiro, c.1870-1880. Conjunto de litogravuras editadas e encadernadas por George Leuzinger. Reproduçăo fotográfica: Jaime Acioli. 


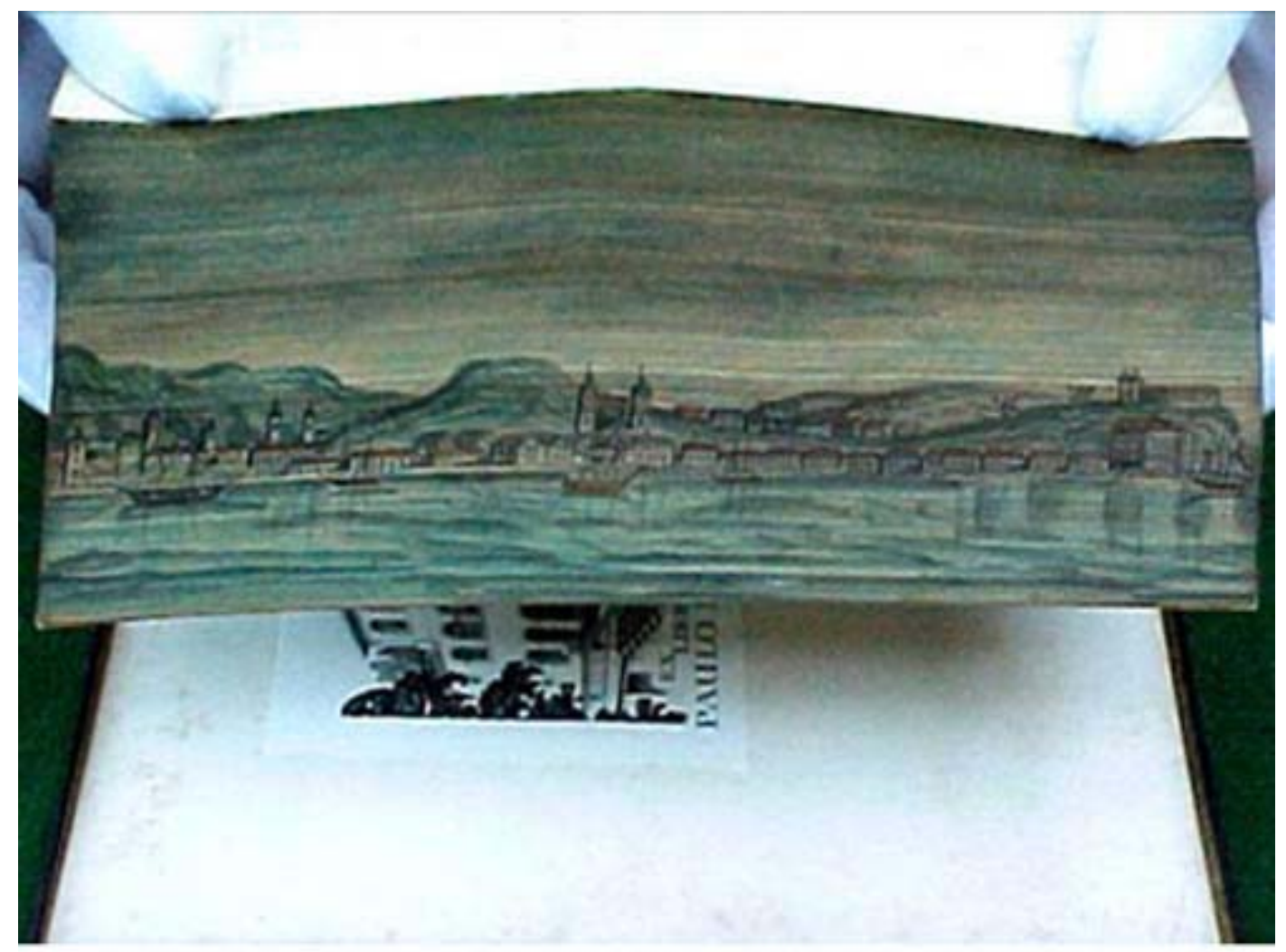

FIGURA 6 - Fore-edge (iconografia em corte frontal da obra) representando a paisagem carioca. Reprodução fotográfica: Pedro Oswaldo Cruz.

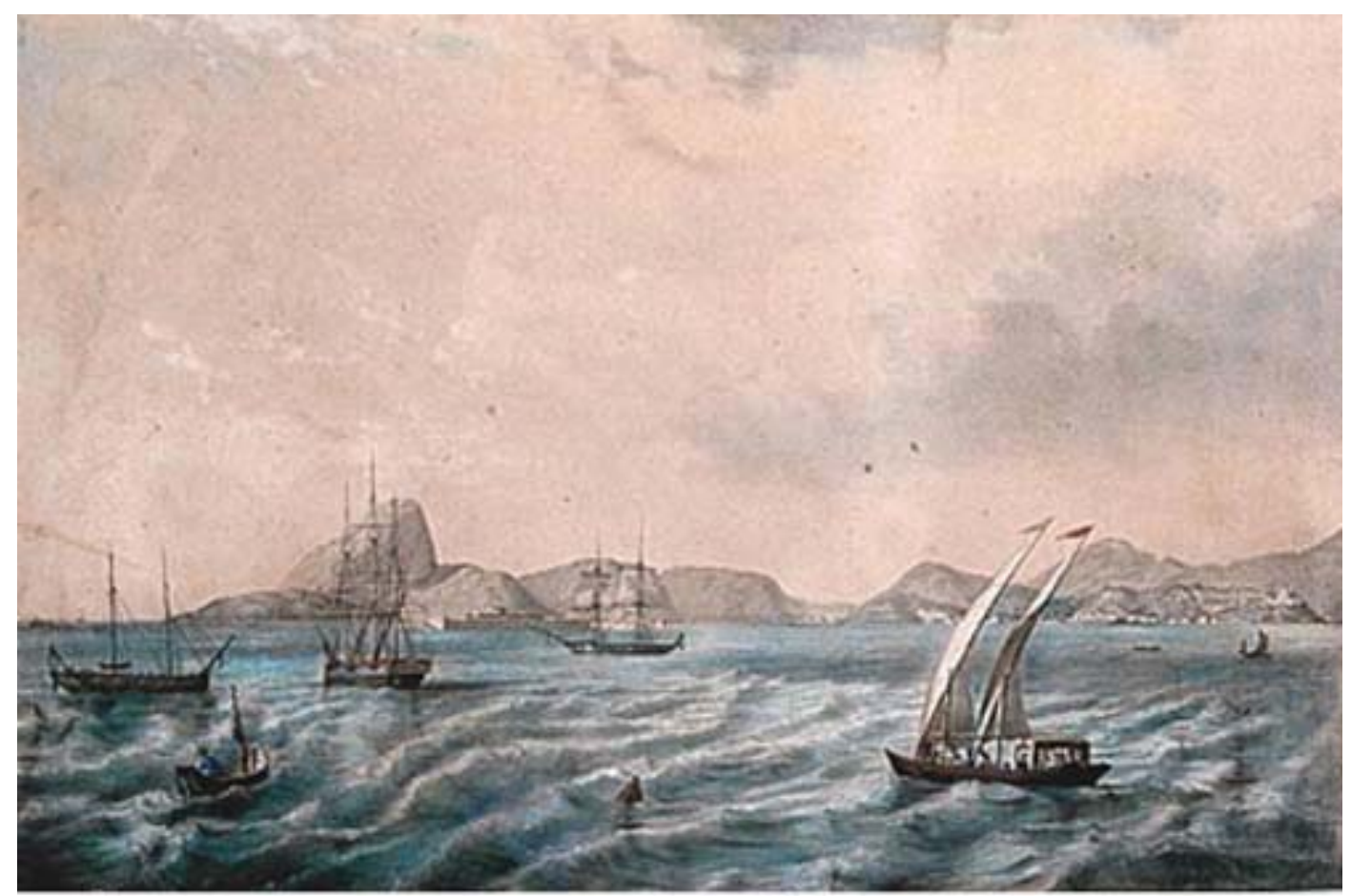

FIGURA 7 - Rio de Janeiro, c. 1845 (primeira parte do panorama circular da baia de Guanabara, da Fortaleza da Laje à Igreja da Glória). Fonte: Warre (desenho) e Joseph Alfred Martinet (litografia) Reproduçăo fotográfica de Pedro Oswaldo Cruz. 


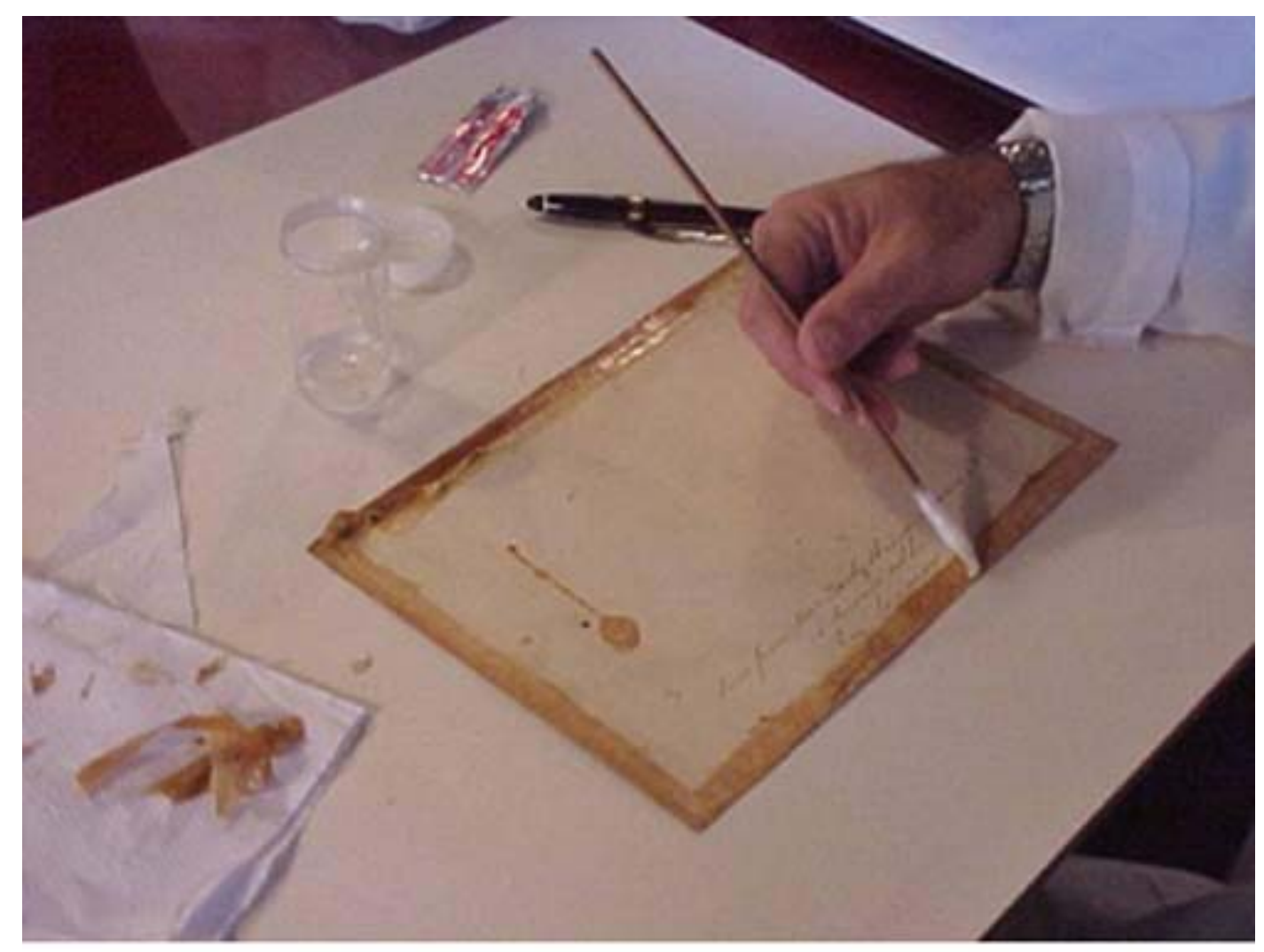

FIGURA 8 - Conservação e restauraçăo das obras em papel da coleção Geyer pela equipe do Museu Imperial. 


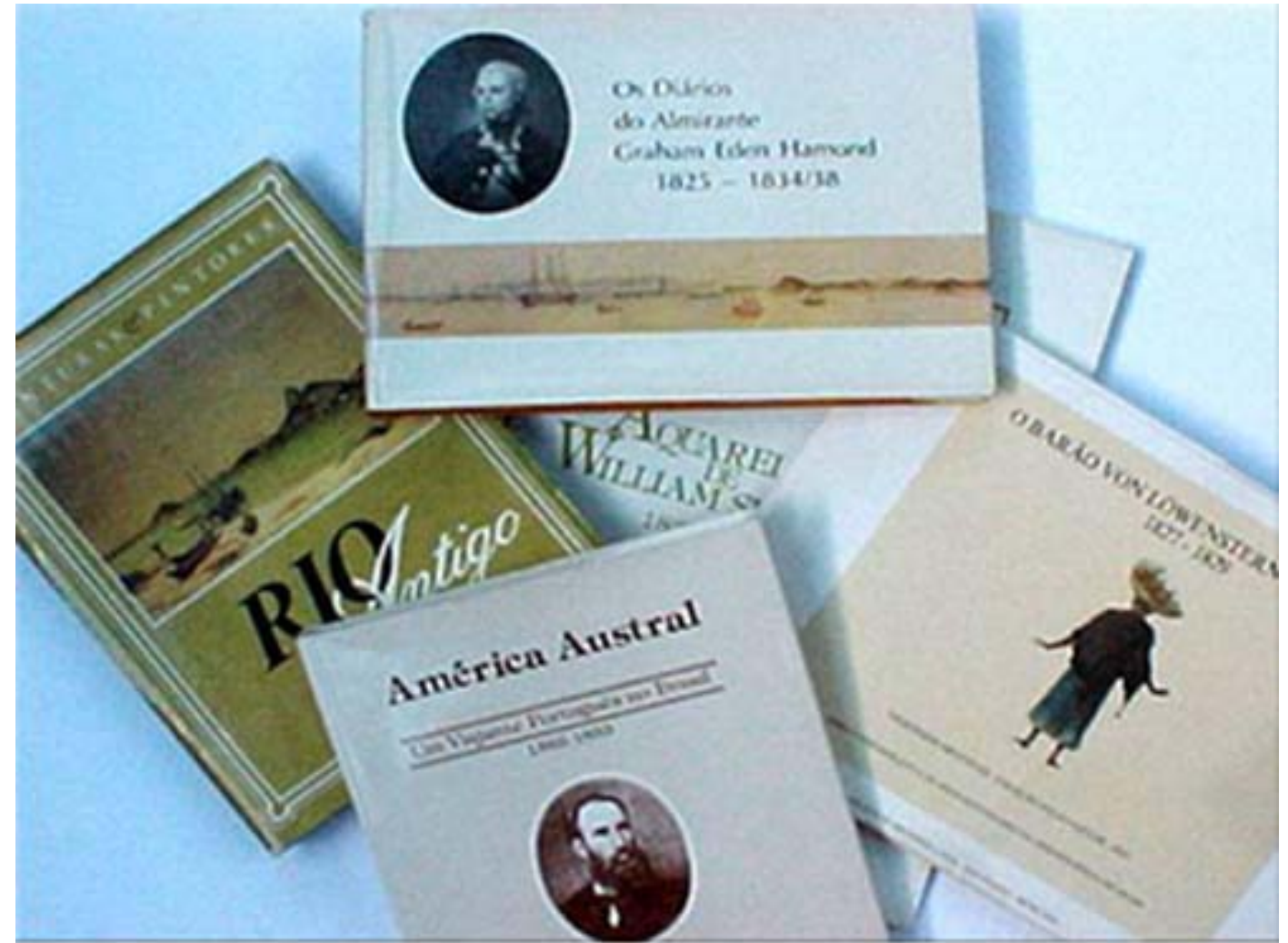

FIGURA 9 - Publicações realizadas por Paulo Geyer sobre sua coleção, antes de doa-la ao Museu Imperial 


\section{VISOEES DO RIO}

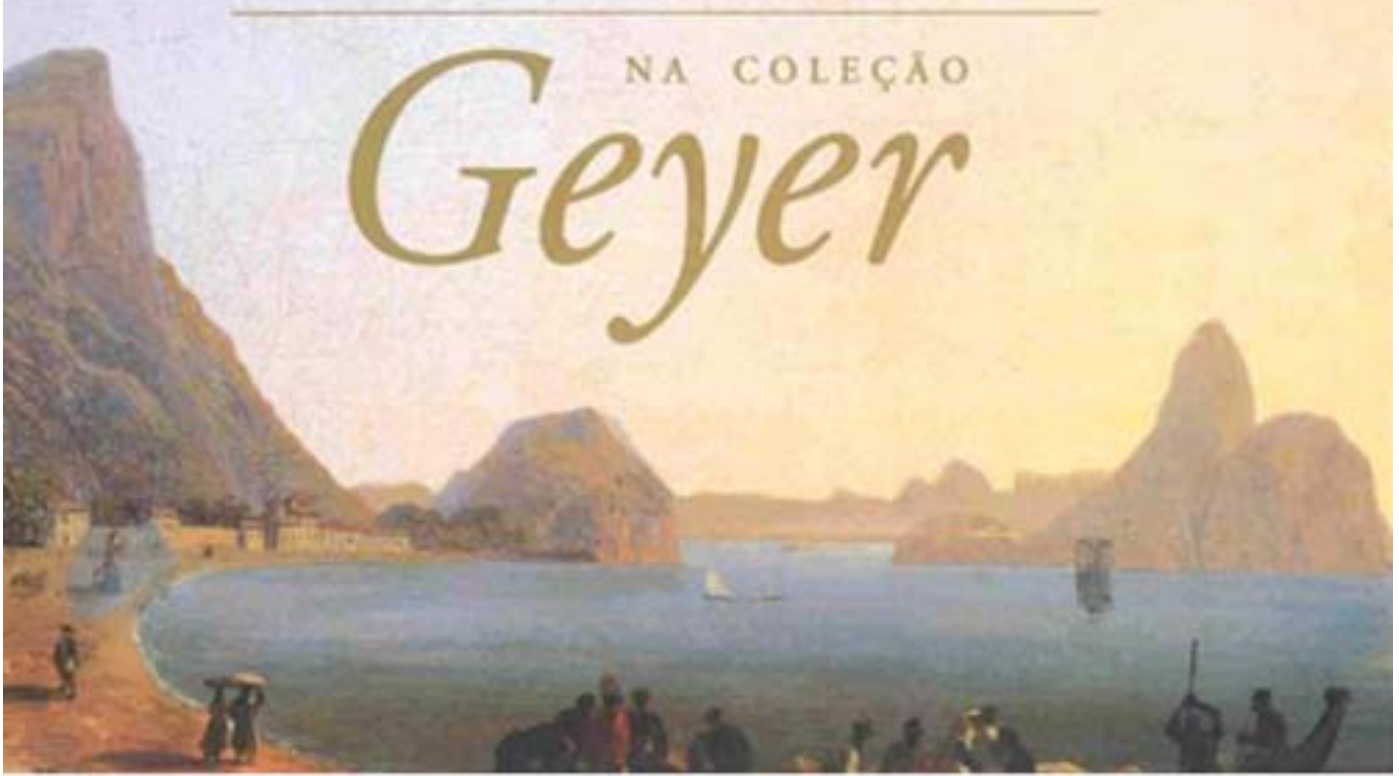

FIGURA 10 - Catálogo da exposição Visões do Rio na coleção Geyer, realizada pelo Museu Imperial, no Centro Cultural Banco do Brasil, no Rio de Janeiro, entre setembro e novembro de 2000

\section{Notas}

(1) Discurso do colecionador Paulo Fontainha Geyer ao receber o Premio Ciccillo Matarazzo, concedido pela Associação Brasileira dos Críticos de Arte, em 20 de julho de 1999.

(2) O nome do empresário Guilherme Guinle (1882-1960) não pode ser esquecido nesta breve referência ao mecenato no Brasil. Dono da Companhia Docas de Santos, ele fez vultosas doações pessoais, por meio da Fundação Gaffrée \& Guinle, para a pesquisa científica, além de destinar aos museus nacionais, na primeira metade do século $X X$, obras de grande valor artístico e histórico.

(3) Vivendo no exílio, o imperador envia uma carta a seu procurador através da qual este ficava autorizado a efetuar a doação de seus livros, documentos e objetos e distribuí-los entre a Biblioteca Nacional, o Instituto Histórico e Geográfico Brasileiro e o Museu Nacional. Para as duas primeiras, havia a recomendação de os livros ocuparem um lugar especial no acervo da instituição, passando a coleção doada pelo imperador a ser denominada "D. Thereza Christina Maria". Para o Museu Nacional, o imperador doou seu museu particular, com material relativo às ciências naturais, mineralogia e herbários e sua coleção deveria aí ser denominada "Imperatriz Leopoldina". Carta de D. Pedro II a José da Silva Costa, 8 de junho de 1891. Coleção Silva Costa. Arquivo Histórico do Museu Imperial. 
(4) Cf. TURAZZI, Maria Inez. A comunicabilidade de uma coleção. In: HORTA, Maria de Lourdes P. et al. Visões do Rio na coleção Geyer. Rio de Janeiro: Museu Imperial, 2000.

(5) Em sentido restrito, uma brasiliana compreenderia "todos os livros sobre o Brasil, impressos desde o século XVI até fins do século XIX, e os livros de autores brasileiros, impressos no estrangeiro até 1808". Cf. MORAES, Rubens Borba de. O bibliófilo aprendiz. 4 ed. Rio de Janeiro: Casa da Palavra; Lemos Informação e Comunicação, 2005, p. 176. Em sentido mais amplo, no entanto, o termo costuma englobar também a iconografia sobre o Brasil produzida no mesmo período e, até mesmo, obras impressas no Brasil depois de 1808 (a chamada "brasiliense", como propõe o mesmo autor).

(6) Além de objetos que existiam nos antigos Paços imperiais (Cidade, São Cristóvão, Petrópolis e Santa Cruz) e em instituições públicas (Palácio Itamaraty, Tesouro Nacional, Casa da Moeda, Museu Nacional, Palácio do Catete), o museu recebeu importantes doações de bens da família imperial leiloados depois da Proclamação da República, então reunidos por colecionadores como Guilherme Guinle, Lineu de Paula Machado, família Modesto Leal, entre outros. Cf. SODRÉ, Alcindo. Museu Imperial. Rio de Janeiro: Imprensa Nacional, 1950.

(7) BRASIL. Decreto $n^{\circ}$ 39.446, de 21 de junho de 1956, assinado pelo presidente Juscelino Kubitschek, que "aceita o legado feito à União de um imóvel em Petrópolis, estado do Rio de Janeiro, para a instalação da Casa de Cláudio de Souza".

(8) Estavam presentes ao evento, além do casal Geyer, familiares e colaboradores, o Ministro da Cultura Francisco Weffort, a Diretora do Museu Imperial, Maria de Lourdes Parreiras Horta, o Secretário de Patrimônio, Otávio Elíseo, o presidente do Instituto do Patrimônio Histórico e Artístico Nacional, Carlos Henrique Heck, o presidente do Conselho Editorial do Jornal do Brasil, M.F. do Nascimento Brito, funcionários das instituições citadas e outras personalidades.

(9) Construída na segunda metade do século XIX, a casa pertenceu ao engenheiro João Teixeira Soares, responsável por algumas das mais importantes obras de engenharia ferroviária de sua época, entre as quais a Estrada de Ferro do Corcovado. O engenheiro era bisavô de dona Maria Cecília Geyer.

(10) Carta de Enéas Martins Filho a Alberto Lee, datada de 3 de março de 1965, encontrada junto a uma publicação do historiador existente na coleção Geyer.

(11) Cf. P. Heymann. Um recanto pitoresco do Rio antigo. In: EICHNER, Erich (org). Cidade e arredores do Rio de Janeiro: a jóia do Brasil. Rio de Janeiro: Kosmos, [1944].

(12) Ver, por exemplo, BERGER, Paulo. Bibliografia do Rio de Janeiro de viajantes e autores estrangeiros. 15311900. Rio de Janeiro: São José, 1964 e O Rio de ontem no cartão postal. 1900-1930. Rio de Janeiro: Rioarte, 1983, entre outras obras.

(13) Cf. BERGER, Paulo. Usos e costumes do Rio de Janeiro nas figurinhas de Guillobel. Rio de Janeiro, 1978. Edição do colecionador Cândido Guinle de Paula Machado.

(14) Cf. FERREZ, Gilberto. Iconografia do Rio de Janeiro. 1530-1890. Rio de Janeiro: Casa Jorge Editorial, 2000. 
(15) BIBLIOTECA NACIONAL. Lembranças do Brasil - Ludwig and Briggs. Rio de Janeiro, 1970. Edição facsimilar do álbum original, com introdução de Lygia da Fonseca Fernandes da Cunha.

\section{Referências Bibliográficas}

BERGER, Paulo. Bibliografia do Rio de Janeiro de viajantes e autores estrangeiros. 1531-1900. Rio de Janeiro: São José, 1964.

Usos e costumes do Rio de Janeiro nas figurinhas de Guillobel. Rio de Janeiro, 1978.

O Rio de ontem no cartão postal. 1900-1930. Rio de Janeiro: Rioarte, 1983.

BIBLIOTECA NACIONAL. Catálogo da Exposição de História do Brasil realizada pela Bibliotheca Nacional do Rio de Janeiro a 2 de dezembro de 1881. Rio de Janeiro: Typ. de G. Leuzinger \& Filhos, 1881. 2v.

Lembranças do Brasil - Ludwig and Briggs. Rio de Janeiro, 1970.

CERTEAU, Michel de. A operação histórica. In: LE GOFF, Jacques; NORA, Pierre. História: novos problemas. Rio de Janeiro: F. Alves, 1976.

CUNHA, Lygia da Fonseca Fernandes da. Rio de Janeiro - Visões do passado - Coleção de Paulo Geyer. Rio de Janeiro: Galeria IBEU, 1972. Catálogo da exposição.

DEBRET, Jean-Baptiste. Voyage pittoresque et historique au Brésil. Paris: Firmin Didot, 1834-1839, v.III.

FERREZ, Gilberto. Iconografia do Rio de Janeiro. 1530-1890. Rio de Janeiro: Casa Jorge Editorial, 2000.

GEYER, Paulo F. (org.). Os diários do almirante Graham Eden Hamond 1825 - 1834 / 1838. Rio de Janeiro: JB, 1984. Tradução do organizador.

HEYMANN, P. Um recanto pitoresco do Rio antigo. In: EICHNER, Erich (org). Cidade e arredores do Rio de Janeiro: a jóia do Brasil. Rio de Janeiro: Kosmos, [1944].

HORTA, Maria de Lourdes P. et al. Visões do Rio na coleção Geyer. Rio de Janeiro: Museu Imperial, 2000.

KIDDER, Daniel P. Reminiscências de viagens e permanência no Brasil (Rio de Janeiro e província de São Paulo). São Paulo: Martins Fontes, 1940. A edição original é de 1857.

ROUSSO, Henry (pres.). Le regard de l'Histoire: l'émergence et l'évolution de la notion de patrimoine au cours du XXe siècle en France. Paris: Éditions du Patrimoine; Fayard, 2003. Actes des Entretiens du Patrimoine, esp.

SODRÉ, Alcindo. Museu Imperial. Rio de Janeiro: Imprensa Nacional, 1950.

TURAZZI, Maria Inez. A comunicabilidade de uma coleção. In: HORTA, Maria de Lourdes P. et al. Visões do Rio na coleção Geyer. Rio de Janeiro: Museu Imperial, 2000.

Revista CPC, São Paulo, v.1, n.2, p.47-79, maio/out. 2006 
O bulício das ruas na litografia Briggs. In: TURAZZI, Maria Inez (org.). Tipos e cenas no Brasil imperial: a litografia Briggs na coleção Geyer. Petrópolis: Museu Imperial, 2002.

* Historiadora. Pesquisadora do Museu Imperial - IPHAN / MinC, Coordenadora do Projeto de Inventário e Conservação da Casa Geyer.

Agradeço o apoio dado à elaboração deste texto por Claudia M. de Souza Costa, Dora P. Rego Correa, Heitor Coutinho, Laura X. Pessoa, Maria Antonieta A. da Silva, Maria de Fátima M. Argon, Maria de Lourdes P. Horta, Maria Isabel R. Lenzi, Maurício V. Ferreira Junior, Mônica Zaias e Neibe Machado da Costa. 